\title{
The Relationship Between Country Branding Components and Competitive Advantage
}

\author{
Tevfik Şükrü YAPRAKLI*
}

Ali ABSALAN**

Musa ÜNALAN ${ }^{* * *}$

\begin{abstract}
The goal of the current research work is examining the association between competitive advantage and country branding in view of citizens. Country branding is the core of managing which plays a vital role in managing the sustainable competitiveness of a nation. Country competitiveness is a concept which shows the degree to which a country can be differentiated from its rivals in the field of global competition. Data collected from Erzurum in Turkey and Urmia in Iran. Convenience sampling method was used in this study. Having determined the validity of data through excluding the missing inputs, 604 subjects were obtained to in order to conduct the considered analysis. Participants of the study involved 286 and 318 individuals from Turkey and Iran countries, respectively. Turkish citizens exhibited higher levels of emotional, physical, financial and social appeal than Iranian citizens. In addition, there was a significant positive correlation between physical, financial and leadership components and competitive advantage in both countries.
\end{abstract}

Key Words: Country Branding, Competitive Advantage, Turkey, Iran

JEL Classification: M30, M31, N30

\section{Ülke Markalama Bileşenleri ile Rekabetçi Avantaj Arasındaki İlişki}

\section{$\ddot{O} Z$}

Bu çalışmanın amacı rekabet avantajı ile ülke markalaması arasındaki ilişkiyi vatandaşların algıları üzerinden incelemektir. Ülke markalaması, bir ulusun sürdürülebilir rekabet edebilirliğinin yönetilmesinde hayati bir rol oynayan yönetimin özüdür. Ülke rekabeti, bir ülkenin küresel rekabet alanındaki rakiplerinden ne kadar farklılaşabileceğini gösteren bir kavramdır. Anketler, Türkiye'de Erzurum ve Iran'da ise Urmiye şehrinde yapılmıştır. Anketlerin uygulanmasında, kolayda örnekleme yöntemi kullanılmıştır. Eksik girdiler hariç tutularak verilerin geçerliliği belirlenmiş olup, analizi yapmak için 604 katılımcı dikkate alınmıştır. Çalışmanın Türkiye'deki örneklemini 286, Iran'dakini ise 318 kişi oluşturmaktadır. Çalışmanın sonucunda, Türk vatandaşlarının Iran vatandaşlarına göre kendi ülkelerinin daha fazla duygusal, fiziksel, finansal ve sosyal çekiciliğe sahip olduğunu düşündükleri görülmüştür. Ayrıca her iki ülkede de fiziksel, finansal ve liderlik bileşenleri ile rekabet avantajı arasında pozitif yönlü anlamlı bir ilişki bulunmuştur.

Anahtar Kelimeler: Ülke Markalama, Rekabetçi Avantaj, Türkiye, İran

JEL Sinıflandirması: M30, M31, N30

\footnotetext{
*Prof. Dr., Atatürk Üniversitesi, İktisadi ve İdari Bilimler Fakültesi, İşletme Bölümü, sukruyaprakli@ atauni.edu.tr, ORCID Bilgisi: 0000-0002-1756-1491

${ }^{* *}$ Yüksek Lisans Öğrencisi, Atatürk Üniversitesi, Üretim Yönetimi ve Pazarlama Bilim Dall, ali.absalan69@gmail.com, ORCID Bilgisi: 0000-0002-6271-7790

${ }^{* * *}$ Arş. Gör., Fırat Üniversitesi, İktisadi ve İdari Bilimler Fakültesi, İşletme Bölümü, munalan@firat.edu.tr, ORCID Bilgisi: 0000-0002-1900-0815
} 


\section{INTRODUCTION}

The rapid development of globalization followed by the raise in competition across markets have encouraged the countries to reflect on themselves in terms of the role they play in the world. It is evident for countries that they are expected to assign an identity which represents their uniqueness from various perspectives. Such an identity would inevitably distinguish them from their counterparts on the global level. Thus, every country endeavor to realize the extent to which its identity can be acknowledged by the global market. To this end, countries around the world compete with one another to share the world's consumers through attracting, cultural events, international sporting and entrepreneurs, tourists, and the people of other countries (Gnoth, 2002: 273). Being acknowledged on the world scope has exerted incentive on the part of countries to specify and develop a brand for themselves which require special strategies to achieve this goal. Of the main targets followed by countries are attracting skilled workers, higher education students, tourists, boosting exports, foreign direct investment (Anholt 2007: 21). Therefore, branding is believed to share ways through adhering to which countries can export their potentials and attain sustainable profits. Consequently, construct a bolstered brand image is a wellknown strategy to challenge for investment and trade.

Numerous scientist have examined country reputation in the subject of nation branding (Anholt, 2005, 2007; Kotler \& Gertner, 2002), effective nation building (Taylor \& Kent, 2006), and strategic public diplomacy (Kruckeberg \& Vujnovic, 2005). Due to significance concerning the term branding, as perceived by most of the countries, both rich and even poor countries make maximum efforts to initiate branding strategies which pave the way for establishing coopetition and success (Hankinson, 2005: 29). Consequently, country branding is an umbrella term and a powerful instrument used to experience competitive advantage. Attaining a plausible level of competitive advantage bears the inference that country has performed successfully in attracting the people, tourists, products, and etc. which are good indicators of how it is distinguished from its rivals (Anholt, 2005: 298).

In the context of branding, one can mention the term differentiation as a crucial factor leading to successful brand identification which is also a measure of how a company is different from its competitors. Such a view has brought the incentive to governments and countries to draw their attention toward differentiating themselves from others with an aim to reach the competitive advantage goal. According to Szondi (2008: 12), "the core idea in nation branding is to identify the uniqueness of the country, its culture or its landscape to identify and draw on features that distinguish and differentiate us from them". Although the notion of country branding is a novel term, it has attracted the attentions as it enforces the companies, governments, and countries to experience and interaction with global competition. Techniques used for country branding can vary from relying on basic physical products to larger and diversified products which can guarantee the differentiation of that country. As it is the case with company's 
market, a country demands to buyers its broad range of gain independently. The crucial thing is is to develop and market recognizable companies for accountable products that can be seperated (Szondi, 2008).

There is limited research on the association between the components of country-branding and competitive advantage in developing countries especially in Turkey and Iran. Therefore, the goal pursued in this research work is addressing the competitive advantage and country branding in view of their citizens. The following three research questions are addressed:

(1) What are the level of perceptions of Turkey in case of country-branding elements among Turkish citizens?

(2) What are the level of perceptions of Iran in case of country-branding elements among Iranian citizens?

(3) What is the association between the components of country-branding and competitive advantage in Turkey and Iran?

This paper has been divided into four parts. The first part addresses the literature and has two sub-sections - country branding and competitive advantage. The second part presents the methodology; the third part describes the outcomes of the research. The fourth and last part presents the conclusion.

\section{LITERATURE REVIEW}

\section{A. Country Branding}

In public diplomacy research, country images and crises has examined by the some scholars (Dai and Chen, 2014). Global institutions and universities observed and measured countries in order to their political stability, morality of their national and international politics, economic development, effectiveness and the appeal of country culture (Werron, 2014). Under these conditions a country's "favorable image and reputation around the world [...] have become more important than territory access, and raw materials" (Gilboa, 2008: 56).

Scientists suggested that country reputation can discuss as a brand image. The reputation of a place is the same as "the nation's image or brand" (Andéhn and Zenker, 2015). Bell (2016: 1) place reputation "can be understood in the context of a lack of a geographical understanding of the reputations of cities and regions". Lucarelli and Brorström (2013: 65) understand place branding "as the general phenomenon of marketing, branding, promoting, and regeneration of a particular city, region, and/or location".

It is a complicated task to estimate and evaluate country's brand since it concerns the image and reputation which are qualitative concepts. Consequently, to date, there has been no consensus over defining a common model for measuring the mechanism involved in country branding (Olins, 2002: 244).

Branding is a construct which bolsters the future of organization as it helps attaining the determined goals, and country branding seems to be basis for addressing and achieving the country competitiveness. Competitive pressure and expanding market opportunities are the two dimensions influenced by globalization (Kotabe \& Helsen, 2000; Porter, 1998; Barney, 1991). "Globalization promotes locational advantage by removing artificial barriers to trade and investment, which 
provides both the opportunity to boost national competitiveness and a threat to increasing or even maintaining it" (Porter, 1998: 25). It is strongly believed by researchers such as Anholt (2005: 230) that country branding is a powerful tool which rises an optimum level of competitive advantage within the country. It is also claimed by the same author that "Globalization leads to countries competing with each other for the attention, respect and trust of investors, tourists, consumers, donors, immigrants, the media, and the governments of other nations" (2005: 25).

The concept of country branding has a bi part to play for country competitiveness since poor performance, weakened products and services, and negative attitude in this domain can blur the reputation and its capability for competing on the global level. Therefore, one can demonstrate that a country can benefit from effective branding as it leads to the competitive advantage. Countries should compensate their poor performance through practicing those strategies which help them blossom in terms of maintaining unique features. In this respect, Anholt (2007: 16) asserts "far from maintaining such inequalities the practice of country branding presents a unique opportunity for underprivileged nations to benefit from a redistribution of wealth through contributing to the creation of successful local brands rather than merely acting as sources of cheap production for rich countries' brands". Consequently, country branding is viewed as "the basis through relying on which countries can gain access to sophisticated and lucrative developed markets" (Lodge, 2002: 71).

Countries understand the importance of reputation for their benefits. In the world, every country want to perceive a good country in people minds, because "'national reputation is unquestionably an instrument of power"' (Wang 2006: 91). Reputation is a soft power (Nye, 2004). Countries with a good names in the world have increased tourism revenues (Stock 2009; Kiambi 2017). If countries have favorable reputation, they can be as a place where direct foreign investment and talent people attract (Kotler and Gertner 2002). Also, it will increase companies products and services in international market (Stock 2009). Country reputation is defined as "perceptions of a country over time based on direct and indirect experiences with the country as compared with its competitors', (Kiambi 2017: 62).

One of the characteristics of successful branding is its strength to yield products and services which make them so outstanding that it is distinguished from other competitors (Aaker 1996: 102). In this regard, Kotler and Keller (2006: 15) emphasize "a country that manages its reputation organically and applies a seamless long term strategy in the way it is positioned, portrayed or represented can enjoy an enhanced international image and achieve its objectives in the global marketplace".

Simon Anholt, the pioneering figure in studies of marketing, is taken into consideration as the sole reference of providing reliable and numerical data dealing with assumed brands. What is followed in evaluating the country branding is to categorize the components by the following items, namely, emotional, physical, financial, leadership, cultural, and social. What is pursued is to provide a complete measurement concerning the worldwide reputation of a nation based on which 
upcoming endeavors are done. However, it is unclear if such a methodology can be practiced effectively on the global level (2005: 302).

Yang et al. (2008, 424-425) define each dimensions as follows:

1. Emotional appeal: What people think a country in terms of its respected, liked, and admired;

2. Physical appeal: What people think a country in terms of its health care, housing, roads, services, and communications;

3. Financial appeal: What people think a country in terms of its growth prospects, competitiveness, profitability, and risk of investment;

4. Leadership appeal: What people think a country as a leadership and communication;

5. Cultural appeal: What people think a country in terms of its culture and a history;

6. Social appeal: What people think a country in terms of its support to global community, environmental policies, good causes.

\section{B. Competitive Advantage}

They key to country's prosperity is competitiveness which depends on the extent to which productivity exists in order to deliver and offer good and services. What guarantees a prosperous economy is not solely the existence of political, legal and social institutes which build up the macro dimension; rather, there are other elements which hare at work in this regard. Factors such as competitiveness are the essence of success in this domain which have roots in micro dimension of economy the sophistication of company operations and strategies and the quality of the microeconomic business context which involves companies' competition (Martinovi, 2002: 3019).

Country competitiveness is a concept which shows the degree to which a country can be differentiated from its rivals in the field of global competition (Porter, 1990; Kotler 1998; Gudjonsson, 2005; Gilmore, 2002). Researches have suggested various methods through the use of which ne can specify country's competitiveness. As an example in case, Porter developed his model based on the study he conducted among ten countries whose ultimate purpose was to attain competitive advantage dealing with several industry sectors. Gilmore (2002:112) mentioned that "many industries, and especially in distinct segments of industries, competitors with true international competitive advantage are based in only a few countries and certain characteristics of the country make them the home base of these leading firms". This, it is the industry of a country which can be a good and reliable indicator of the extent to which the country has enjoyed competitive advantage. Enjoying competitive advantage in one sector is one way to ensure the same advantages in corresponding sectors as suggested by Porter (1990).

The ultimate purpose of competition among countries when it come to the global environment is to prepare themselves to establish markets, technology, environment and skills to increase the standards dealing with living. The extent to which a company is successful in achieving its leading targets is its share of competitiveness, but the quality of addressing and embarking on this notion is 
under question. As put forth by Lee (2009: 64), "as branding is referred to as the starting point in creating a sustainable future for the organization, country branding can be considered to be the central concept in managing and managing the sustainable competitiveness of a nation". So far, there has been no consensus over a unit and general definition on competitiveness; however, different researchers have raised their viewpoints toward this very concept (Pike, 2014: 217).

The first step toward competitiveness for countries is to reflect on their powers, talents, abilities, and skills which ensure attracting both human and physical capital from national and international scopes. What the notion of competitiveness delivers is the extent to which a country represents its capability to attain and develop resources as far as national or international needs are concerned with the purpose of reaching the competitive advantage (Mihailovich, 2006: 240). The outcome of competitiveness is not unilateral, i.e. it is based on a dynamic path which does not set boundaries into the process of competitiveness as suggested by Buckley, Pass, and Prescott (1988). The key for competitiveness is for the country to make its goods and services consistent with the international markets.

\section{METHODOLOGY}

\section{A. Research Model and Hypotheses}

The relations between the country branding dimensions and competitive advantage constructs are hypothesized in the model (Fig. 1).

$\mathbf{H}_{1}$ : Emotional element of country-branding is positively related to competitive advantage.

$\mathbf{H}_{2}$ : Physical element of country-branding is positively related to competitive advantage.

$\mathbf{H}_{3}$ : Financial element of country-branding is positively related to competitive advantage.

$\mathbf{H}_{4}$ : Leadership element of country-branding is positively related to competitive advantage.

H5: Cultural element of country-branding is positively related to competitive advantage.

$\mathbf{H}_{6}$ : Social element of country-branding is positively related to competitive advantage. 
Figure 1. Research Model

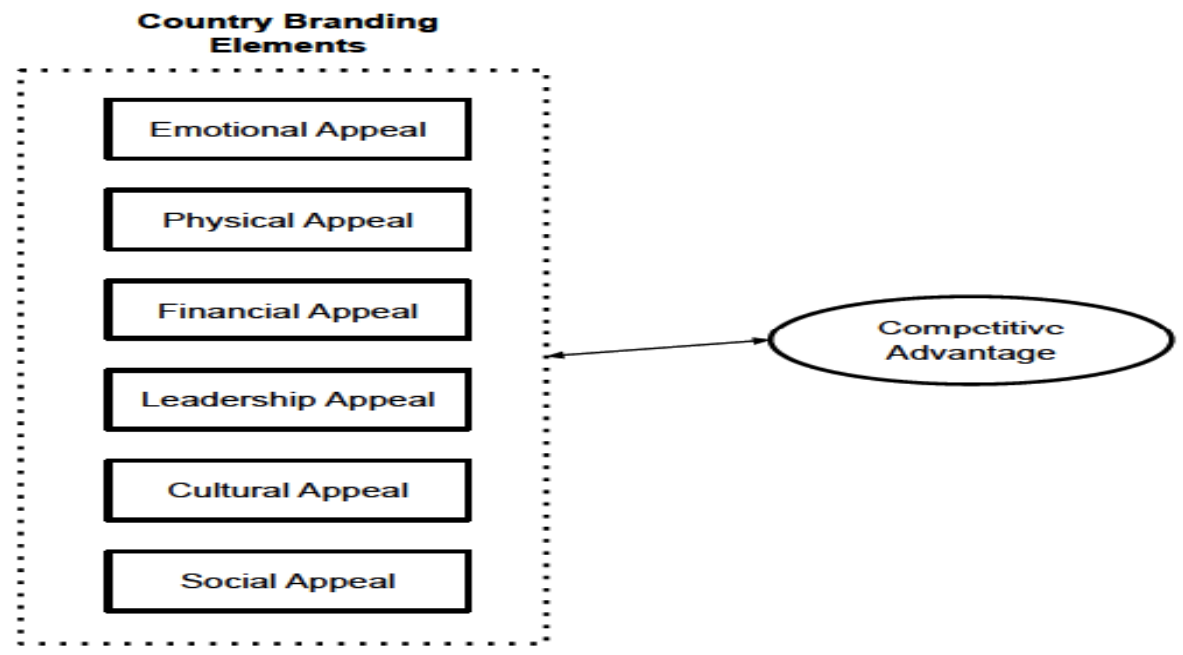

\section{B. Data Collection and Procedure}

We used convenience sampling method in this research. Data collected from Urmia in Iran and Erzurum in Turkey. The target population for the person administered survey was local people in these cities. Over a period of four weeks, participants intercepted at the Ataturk University, Urmia University and other places in cities. About 330 questionnaires were distributed each city and totally 648 completed questionnaires were received. Having determined the validity of data through excluding the missing inputs, 604 subjects were obtained to in order to conduct the considered analysis. Participants of the study involved 286 and 318 individuals from Turkey and Iran countries, respectively.

\section{Measures}

We observed the country-branding elements as follows: (1) emotional appeal was measured using three items from Passow, Fehlmann and Grahlow (2005). (2) We measured physical appeal by a three-item scale from Passow et al. (2005). (3) With respect to financial appeal, we used a four-item scale from Passow et al. (2005). (4) We measured leadership appeal using a four-item scale from Passow et al. (2005). (5) With the cultural appeal, we used a three-item scale from Passow et al. (2005). (6) Finally, for the social appeal, a three-item scale from Passow et al. (2005) were used. (7) Lastly, we measured competitive advantage by adapting eight scales from Gudjonsson (2005), Kotler and Gertner (2002), and Wee (1994). We employed five-point scales for all measures: 'strongly disagree', 'disagree', '...', and 'strongly agree'.

\section{Statistical Analysis}

Using the SPSS 22 statistical package, the study's results include overall descriptive statistics results, correlation results, and hypothesis results for competitive advantage with country-branding elements. 


\section{RESULTS}

\section{A. Sample Profile}

A total of 604 responses were collected in Turkey and Iran. 286 complete responses were used as the Turkish sample for further analyses. For Iranian sample, a total of 318 completed questionnaires were used for the final data analyses. The samples also showed that respondents with heterogeneous profile participated in the survey (see Table 1 for details).

Table 1. Sample Profile

\begin{tabular}{|c|c|c|c|c|c|}
\hline \multirow{2}{*}{$\begin{array}{l}\text { Variable } \\
\text { Gender }\end{array}$} & \multirow[t]{2}{*}{ Category } & \multicolumn{2}{|c|}{$\begin{array}{l}\text { Turkey } \\
(\mathbf{n}=\mathbf{2 8 6})\end{array}$} & \multicolumn{2}{|c|}{$\begin{array}{c}\text { Iran } \\
(\mathbf{n}=\mathbf{3 1 8})\end{array}$} \\
\hline & & Number & Percent & Number & Percent \\
\hline & Male & 152 & 53.1 & 145 & 45.6 \\
\hline & Female & 134 & 46.9 & 173 & 54.4 \\
\hline \multicolumn{6}{|c|}{ Education } \\
\hline & Primary education & 4 & 1.7 & 1 & 0.3 \\
\hline & High school & 7 & 2.4 & 12 & 3.8 \\
\hline & College & 31 & 10.8 & 24 & 7.5 \\
\hline & Undergraduate & 184 & 64.3 & 165 & 51.9 \\
\hline & Master and doctorate & 60 & 20.9 & 116 & 36.5 \\
\hline \multicolumn{6}{|c|}{ Income level } \\
\hline & Below 1000 Turkish Lira & 146 & 51.0 & 105 & 33.0 \\
\hline & $1001-2500$ & 70 & 24.5 & 137 & 43.1 \\
\hline & $2501-4000$ & 37 & 12.9 & 61 & 19.2 \\
\hline & $4001-5500$ & 27 & 9.4 & 14 & 4.4 \\
\hline & Above 5501 & 6 & 2.1 & 1 & 0.3 \\
\hline \multicolumn{6}{|l|}{ Age } \\
\hline & $18-27$ & 138 & 48.3 & 100 & 31.4 \\
\hline & $28-37$ & 82 & 28.7 & 119 & 37.4 \\
\hline & $38-47$ & 29 & 10.1 & 28 & 8.8 \\
\hline & $48-57$ & 18 & 6.3 & 43 & 13.5 \\
\hline & 58 and over & 19 & 6.6 & 28 & 8.8 \\
\hline \multicolumn{6}{|l|}{ Job } \\
\hline & Student & 156 & 54.5 & 77 & 24.2 \\
\hline & Worker & 10 & 3.5 & 1 & 0.3 \\
\hline & Officer & 33 & 11.5 & 38 & 11.9 \\
\hline & Self-employment & 16 & 5.6 & 47 & 14.8 \\
\hline & Retired & 30 & 10.5 & 60 & 18.9 \\
\hline & Private sector employee & 34 & 11.9 & 72 & 22.6 \\
\hline & Housewife & 4 & 2.4 & 23 & 7.2 \\
\hline
\end{tabular}

Of the Turkish sample, 53 per cent of the respondents were male and 47 per cent were female. Highest level of education achieved was mostly 64.3 per cent Bachelor's degree. Income level ranged from less than 1000 Turkish Lira to more than above 5501 Turkish Lira, with a median income group below 1000 Turkish Lira. Age ranged from 18 to 58 and over years, with a median age of 18 to 27 years. The majority of respondents were students ( 54.5 per cent), followed by private sector employee (11.9 per cent). Of the Iranian sample, 45.6 per cent of the respondents were male and 54.4 per cent were female. Highest level of education achieved was mostly 51.9 per cent Bachelor's degree. Income level ranged from less than 1000 Turkish Lira to more than above 5501 Turkish Lira, with a median income group between 10001 and 2500 Turkish Lira. Age ranged from 18 to 58 and over years, with a median age of 28 to 37 years. The majority of respondents were students ( 24.2 per cent), followed by private sector employee ( 22.6 per cent) 
Table 2 displays the perceptions of citizens in order to each of the variables for both countries.

Table 2. Means and Standard Deviations of Country Branding Elements and Competitive Advantage

\begin{tabular}{|c|c|c|c|c|}
\hline & \multicolumn{2}{|c|}{ Turkey $(n=286)$} & \multicolumn{2}{|c|}{ Iran $(n=318)$} \\
\hline & Mean & $\begin{array}{l}\text { Standard } \\
\text { Deviation }\end{array}$ & Mean & $\begin{array}{l}\text { Standard } \\
\text { Deviation }\end{array}$ \\
\hline Emotional Appeal & 4.60 & 0.49 & 4.53 & 0.51 \\
\hline I respect Turkey/Iran & 4.54 & 0.62 & 4.68 & 0.49 \\
\hline I like Turkey/Iran & 4.77 & 0.46 & 4.58 & 0.56 \\
\hline I trust Turkey/Iran & 4.50 & 0.75 & 4.34 & 0.78 \\
\hline Physical Appeal & 4.14 & 0.50 & 4.11 & 0.58 \\
\hline Turkey/Iran is a beautiful place & 4.67 & 0.50 & 4.70 & 0.58 \\
\hline Turkey/Iran has well-educated residents & 3.89 & 0.82 & 4.08 & 0.73 \\
\hline $\begin{array}{l}\text { Turkey/Iran has good infrastructure of roads, housing, } \\
\text { services, healthcare, and communications }\end{array}$ & 3.85 & 0.80 & 3.55 & 0.96 \\
\hline Financial Appeal & 3.24 & 0.68 & 3.60 & 0.63 \\
\hline Turkey/Iran is an inviting place to do business & 3.88 & 0.83 & 3.85 & 0.79 \\
\hline Turkey/Iran has a well-developed industrial sector & 3.43 & 1.01 & 3.38 & 0.85 \\
\hline Turkey/Iran is a low tax country & 2.03 & 0.93 & 3.61 & 0.81 \\
\hline Turkey/Iran is a safe place in which to invest & 3.62 & 0.99 & 3.58 & 1.00 \\
\hline Leadership Appeal & 3.59 & 0.88 & 3.36 & 0.70 \\
\hline Turkey/Iran has charismatic leaders & 3.49 & 1.02 & 3.43 & 0.97 \\
\hline $\begin{array}{l}\text { Turkey/Iran communicates and appealing vision of } \\
\text { the country }\end{array}$ & 3.77 & 0.93 & 3.50 & 0.90 \\
\hline Turkey/Iran a is well-managed & 3.48 & 1.12 & 3.13 & 0.86 \\
\hline Turkey/Iran upholds international laws & 3.63 & 1.06 & 3.40 & 0.78 \\
\hline Cultural Appeal & 4.33 & 0.42 & 4.26 & 0.44 \\
\hline Turkey/Iran is socially and culturally diverse & 4.30 & 0.61 & 4.57 & 0.56 \\
\hline Turkey/Iran has a rich historical past & 4.74 & 0.46 & 4.81 & 0.41 \\
\hline Turkey/Iran offers enjoyable entertainment activities & 3.94 & 0.89 & 3.39 & 1.09 \\
\hline Social Appeal & 3.70 & 0.69 & 3.63 & 0.76 \\
\hline Turkey/Iran supports good causes & 3.82 & 0.79 & 3.67 & 0.94 \\
\hline $\begin{array}{l}\text { Turkey/Iran is a responsible member of the global } \\
\text { community }\end{array}$ & 3.69 & 0.91 & 3.68 & 0.93 \\
\hline $\begin{array}{l}\text { Turkey/Iran supports responsible environmental } \\
\text { policies }\end{array}$ & 3.58 & 0.89 & 3.54 & 0.93 \\
\hline Competitive Advantage & 3.88 & 0.62 & 3.95 & 0.57 \\
\hline Turkey/Iran is capable in attracting tourists & 4.22 & 0.74 & 4.13 & 0.83 \\
\hline $\begin{array}{l}\text { Turkey/Iran has knowledgeable and skillful human } \\
\text { capital }\end{array}$ & 4.06 & 0.79 & 4.14 & 0.79 \\
\hline Turkey/Iran tends to outperform its competitors & 3.85 & 0.85 & 3.75 & 0.78 \\
\hline $\begin{array}{l}\text { Turkey/Iran is capable in generating harmony and } \\
\text { stable society }\end{array}$ & 3.60 & 0.95 & 3.77 & 0.82 \\
\hline $\begin{array}{l}\text { Turkey/Iran is capable in maintaining political } \\
\text { stability }\end{array}$ & 3.50 & 1.06 & 3.99 & 0.94 \\
\hline $\begin{array}{l}\text { Turkey/Iran is capable in producing world-class } \\
\text { export brand }\end{array}$ & 3.74 & 1.00 & 4.02 & 0.85 \\
\hline $\begin{array}{l}\text { Turkey/Iran is capable in generating more wealth than } \\
\text { its competitors in world }\end{array}$ & 3.99 & 0.88 & 3.90 & 0.80 \\
\hline $\begin{array}{l}\text { Turkey/Iran is capable in producing goods and } \\
\text { services, which meet the standard of the international } \\
\text { markets }\end{array}$ & 4.05 & 0.88 & 3.93 & 0.77 \\
\hline
\end{tabular}

The following are the means, and standard deviations for the emotional appeal dimension: Turkey $(M=4.60, \mathrm{SD}=0.49)$; $\operatorname{Iran}(M=4.53, \mathrm{SD}=0.51)$, physical appeal dimension: Turkey $(M=4.14, \mathrm{SD}=0.50)$; $\operatorname{Iran}(M=4.11, \mathrm{SD}=$ $0.58)$, financial appeal dimension: Turkey $(M=3.24, \mathrm{SD}=0.68)$; $\operatorname{Iran}(M=3.60$, 
$\mathrm{SD}=0.63)$, leadership appeal dimension: Turkey $(M=3.59, \mathrm{SD}=0.88)$; $\operatorname{Iran}(M=$ 3.36, $\mathrm{SD}=0.70)$, cultural appeal dimension: Turkey $(M=4.33, \mathrm{SD}=0.42)$; Iran $(M=4.26, \mathrm{SD}=0.44)$, social appeal dimension: Turkey $(M=3.70, \mathrm{SD}=0.69)$; Iran $(M=3.63, \mathrm{SD}=0.76)$, competitive advantage variable: Turkey $(M=3.88, \mathrm{SD}$ $=0.69)$; Iran $(M=3.95, \mathrm{SD}=0.76)$.

Inter-construct correlations for Turkish sample are presented in Table 3.

Table 3. Correlations of Competitive Advantage with Country Branding Elements: Turkish

Citizens' View Towards Turkey

\begin{tabular}{lll}
\hline Competitive advantage (mean: 3.87) is correlated with & $\boldsymbol{r}$ & Sig. \\
\hline Emotional appeal (mean: 4.60) & $0.213^{* *}$ & 0.000 \\
Physical appeal (mean: 4.14) & $0.269^{* *}$ & 0.000 \\
Financial appeal (mean: 3.24) & $0.277^{* *}$ & 0.000 \\
Leadership appeal (mean: 3.59) & $0.432^{* *}$ & 0.000 \\
Cultural appeal (mean: 4.33) & 0.080 & 0.175 \\
Social appeal (mean: 3.70) & $0.371^{* *}$ & 0.000 \\
\hline
\end{tabular}

Notes: *** Correlation is significant at the 0.05 and 0.01 levels (2-tailed), respectively

Correlation analyses indicated several significant relationships (see Table 1). Specifically, consistent with our predictions, competitive advantage was positively related with emotional $\left(p<0.01, r=0.213^{* *}\right)$, physical $(p<0.01$, $\left.r=0.269^{* *}\right)$, financial $\left(p<0.01, r=0.277^{* *}\right)$, leadership $(p<0.01, r=0.432 * *)$, and social appeals $\left(p<0.01, r=0.371^{* *}\right)$. Therefore, H1, H2, H3, H4 and $\mathrm{H} 6$ are supported. Cultural appeal $(p>0.05, \quad r=0.080)$ does not significantly predict competitive advantage. Thus, H5 is not supported.

Inter-construct correlations for Iranian sample are presented in Table 4.

Table 4. Correlations of Competitive Advantage with Country Branding Elements: Iranian Citizens'

View Towards Iran

\begin{tabular}{lll}
\hline Competitive advantage (mean: 4.02) is correlated with & $\boldsymbol{r}$ & Sig. \\
\hline Emotional appeal (mean: 4.48) & 0.075 & 0.181 \\
Physical appeal (mean: 4.11) & $0.178^{* *}$ & 0.001 \\
Financial appeal (mean: 3.60) & $0.134^{*}$ & 0.017 \\
Leadership appeal (mean: 3.36) & $0.163^{* *}$ & 0.004 \\
Cultural appeal (mean: 4.26) & 0.065 & 0.246 \\
Social appeal (mean: 3.63) & 0.070 & 0.214 \\
\hline
\end{tabular}

Notes: *** Correlation is significant at the 0.05 and 0.01 levels (2-tailed), respectively

Correlation analyses indicated several significant relationships (see Table 4). Specifically, consistent with our predictions, competitive advantage was positively related with physical $\left(p<0.01, r=0.178^{* *}\right)$, financial $(p<0.05, r=0.134 *)$, and leadership $(p<0.01, r=0.163 * *)$. Thus, H2, H3 and $\mathrm{H} 4$ are supported. Emotional $(p>0.05, r=0.075)$, cultural $(p>0.05, r=0.065)$, and social appeals $(p>0.05, r=0.070)$ do not significantly predict competitive advantage. Therefore, H1, H5 and H6 are not supported.

Table 5. Testing of Hypotheses

\begin{tabular}{lllll}
\hline & \multicolumn{2}{c}{ Turkey } & Iran \\
\cline { 2 - 5 } H1 & Sig. (2-tailed) & Result & Sig. (2-tailed) & Result \\
\cline { 2 - 5 } H2 & 0.000 & Supported & 0.181 & Not supported \\
H3 & 0.000 & Supported & 0.001 & Supported \\
H4 & 0.000 & Supported & 0.017 & Supported \\
H5 & 0.000 & Supported & 0.004 & Supported \\
H6 & 0.175 & Not supported & 0.246 & Not supported \\
\hline
\end{tabular}




\section{CONCLUSIONS}

The present study investigated the associations between the components of country-branding (emotional, physical, financial, leadership, cultural, social) and competitive advantage in Turkey and Iran. For Turkey, five of six hypotheses are accepted in our model (see Table 5). For Iran, three of six hypotheses are accepted in our model (see Table 5). Our study investigates elements of country branding from the point of view of Turkey and Iran citizens and test these elements against competitive advantage. Turkish citizens exhibited higher levels of emotional, physical, financial and social appeal than Iranian citizens. On the other hand, Iranian citizens performed higher levels of competitive advantage, leadership appeal and cultural appeal than Turkish citizens.

The Turkish citizens evaluated most favorable reputation in the dimension of "emotional appeal," whereas least favorable reputation in the dimension of "financial appeal." The survey respondents in Iran evaluated most favorable reputation in the dimension of "emotional appeal," whereas least favorable reputation in the dimension of "leadership appeal." It means that Turkey's country reputation management should improve financial appeal, leadership appeal, and social appeal. Also, this study suggested that Iran's country reputation management should increase leadership appeal, financial appeal, and social appeal because of least favorable dimensions. Yang et al. (2007) found that American citizens evaluated "leadership appeal" least favorably, "cultural appeal" most favorably for South Korea's country reputation. Kiambi and Shafer (2018) revealed that American public evaluated least favorable dimensions as physical and financial in order to sub-Saharan African countries.

The results also showed that leadership appeal and social appeal were highly correlated with Turkey's country competitive advantage. In Iran, physical appeal was highly correlated with country competitive advantage. The study results support in the literature (Che-Ha et al., 2016). The findings of this study suggest that governmental agencies measure the country image in the view of their citizens and other country's people.

The results aim to help and guide Turkish and Iranian private and public organizations to increase their country image in the view of their citizens. Findings of this research can be useful in terms of nation branding especially in tourism sector. This study revealed useful results for the practice and study of country branding and public diplomacy. It also provides empirical evidence for government managers for campaigns. They also should measure the perceptions of all people in their countries to find best cues. Practitioners of public diplomacy using these findings to think the citizens perceptions of countries their country of interest.

In the future, researchers will examine country branding in the view of government leaders. One limitation of this study was measuring country branding by Turkish and Iranian public. This research cannot be representative of the Turkish and Iranian public demographically. Researchers should explore the relation between country branding and other variables such as intention to visit, buying products and brands in the perspective of country of origin. 
The relationship between competitive advantage and country-branding elements should be investigated in future research with other variables such as political and religion subjects. Also, researchers can use new dimensions such as security, people, and sports appeal for country reputation (Kiambi and Shafer, 2018). They will examine the perceptions of tourists towards Turkey and Iran. And also, they will research the image of countries in the international media with using content analysis.

\section{REFERENCES}

Aaker, D. A. (1996). Measuring Brand Equity Across Products and Markets. California Management Review, Vol. 38, No. 3, 102.

Andéhn, M., Zenker, S. (2015). Place Branding In Systems of Place - On The Interrelation of Nations and Supranational Places (Edited by Zenker, S. and Jacobsen B.P.). Inter-Regional Place Branding, Springer International Publishing, Cham, 25-37.

Anholt S. (2005). Anholt Nation Brands Index: How Does The World See America. Journal of Advertising Research, Vol. 45, No. 3, 296-304.

Anholt, S. (2007). Competitive Identity: The New Brand Management for Nations, Cities and Regions. Houndmills: Palgrave Macmillan.

Barney, J. (1991). Firm Resources and Sustained Competitive Advantage. Journal of Management, Vol. 17, No. 1, 99-120.

Bell, F. (2016). Looking Beyond Place Branding: The Emergence of Place Reputation. Journal of Place Management and Development, Vol. 9, No. 3, 247-254.

Che-Ha, N., Nguyen, B., Yahya, W. K., Melewar, T. C. and Chen, Y. P. (2016). Country Branding Emerging from Citizens' Emotions and the Perceptions of Competitive Advantage: The Case Of Malaysia. Journal of Vacation Marketing, Vol. 22, No. 1, 13-28.

Dai, X. and Chen, G. M. (2014). The Construction of National Image in the Media and the Management of Intercultural Conflicts (Edited by R. S. Fortner \& P. M. Fackler). The Handbook of Media and Mass Communication Theory. John Wiley \& Sons, Inc., 708-725.

Gilboa, E. (2008). Searching for a Theory of Public Diplomacy. The ANNALS of the American Academy of Political and Social Science, Vol. 616, No. 1, 55-77.

Gilmore, F. (2002). A Country-Can It Be Repositioned? Spain - The Success Story of Country Branding. Journal of Brand Management, Vol. 9, No. 4/5, 281-293.

Gnoth, J. (2002). Leveraging Export Brands Through A Tourism Destination Brand. Journal of Brand Management, Vol. 9(4), 262-280.

Gudjonsson, H. (2005). Nation Branding. Place Branding, Vol. 1, No. 3, 283-298.

Hankinson, G. (2005). Destination Brand Images: A Business Tourism Perspective. Journal of Services Marketing, Vol. 19, No. 1, 24-32.

Keller, K. L. (2006). Strategic Brand Management: Building, Measuring and Management Brand Equity. New Jersey: Prentice-Hall.

Kiambi, D. (2017). The Role of Familiarity In Shaping Country Reputation (Edited by J. Fullerton, and A. Kendrick). In Shaping International Public Opinion: A Model For Nation Branding and Public Diplomacy, New York: Peter Lang, 57-75.

Kiambi, D. and Shafer, A. (2018). Country Reputation Management: Developing A Scale for Measuring the Reputation of Four African Countries in the United States. Place Branding and Public Diplomacy, Vol. 14, No. 3, 175-186.

Kotabe, M. and Helsen, C. (2000). Global Marketing Management. John Wiley \& Sons, New York, NY.

Kotler, P. and Gertner, D. (2002). Country as Brand, Product, and Beyond: A Place Marketing and Brand Management Perspective. Journal of Brand Management, Vol. 9, No. 4/5, 249-262.

Kruckeberg, D. and Vujnovic, M. (2005). Public Relations, Not Propaganda, for US Public Diplomacy in A Post-9/11 World: Challenges and Opportunities. Journal of Communication Management, Vol. 9, 296-304. 
Lee, K. M (2009). Nation Branding and Sustainable Competitive of Nations. PhD Dissertation.

Lodge, C. (2002). Success And Failure: The Brand Stories of Two Countries. Journal of Brand Management, Vol. 9(4), 372-384.

Lucarelli, A. Brorström, S. (2013). Problematizing Place Branding Research. The Marketing Review, Vol. 13, No. 1, 65-81.

Martinovi, S. (2002). Branding Hrvatska: A Mixed Blessing that Might Succeed: The Advantage of Being Unrecognizable. Journal of Brand Management, Vol. 9, No. 4, 315-322.

Mihailovich, P. (2006). Place Branding Kinship Branding: A Concept of Holism and Evolution for the Nation Brand. Journal of Brand Management, Vol. 2, No. 3, 229-247.

Morgan, N. J., Pritchard, A. and Pride, R. (2011). Destination Branding: Creating The Unique Destination Proposition. Oxford: Elsevier Limited.

Nye Jr., J. S. (2004). Soft Power: The Means to Success in World Politics. New York: Public Affairs.

Olins, S. (2002). Branding the Nation State, the Historical Context. Journal of Brand Management, Vol. 9, No. 4, 241-248

Passow, T., Fehlmann, R. and Grahlow, H. (2005). Country Reputation - From Measurement to Management: The Case of Liechtenstein. Corporate Reputation Review, Vol. 7, No. 4, 309326.

Pike, S. and Page, S. J. (2014). Destination Marketing Organizations and Destination Marketing: A Narrative Analysis of the Literature. Tourism Management, Vol. 41, 202-227.

Porter, M. (1990). The Competitive Advantage of Nations. Cambridge: Harvard Business Review.

Stock, F. (2009). Identity, Image and Brand: A Conceptual Framework. Place Branding and Public Diplomacy, Vol. 5, No. 2, 118-125.

Sung-Un, Y., Hochang, S., Jong-Hyuk, Lee. and Brenda, W. (2008) Country Reputation in Multidimensions: Predictors, Effects, and Communication Channels. Journal of Public Relations Research, Vol. 20, No. 4, 421-440

Szondil, G. (2008). Public Diplomacy and Nation Branding: Conceptual Similarities and Differences. The Hague: Netherlands Institute of International Relations.

Taylor, M. and Kent, M. L. (2006). Nation-Building: Public Relations Theory and Practice (Edited by V. Hazelton \& C. H. Botan). Public Relations Theory II, Hillsdale, NJ: Lawrence Erlbaum Associates, 341-360.

Wang, J. (2006). Managing National Reputation and International Relations in the Global Era: Public Diplomacy Revisited. Public Relations Review, Vol. 32, 91-96.

Wee, C. H. (1994). Nation Branding Strategies and Economic Development Implications for NIE and LDCs. The International Executive, Vol. 36, No. 2, 119-145.

Werron, T. (2014). On Public Forms of Competition. Cultural Studies-Critical Methodologies, Vol. 14 , No. 1, 62-76.

Yang, S., H. Shin, J. L., and Wrigley, B. (2008). Country Reputation in Multidimensions: Predictors, Effects, and Communication Channels. Journal of Public Relations, Vol. 20, No. 4, 421440. 